\title{
A Case Analysis of E-Government Service Delivery through a Service Chain Dimension
}

\begin{abstract}
Unlike e-business few studies have examined how information is generated and exchanged between stakeholders in an e-government service chain to generate value for citizens. This case study applies the concept of service chains to empirically explore: a) how internal and external business activities in local government authorities (LGAs) contribute to electronic service delivery, and b) the impact that internal and external stakeholders have on these activities. The case study found that the diversity of stakeholders involved and lack of appropriate mechanisms for information exchange and collaboration are posing the biggest challenges for efficient local e-government service delivery.
\end{abstract}

KEYWORDS: E-Government, Service Chains, Local Government, Value, Enterprise Systems

\section{Case Background}

Encouraged by the Internet enabled e-Commerce revolution during the 1990s, public sector organisations embraced the same principles of e-Business through the introduction of national electronic government (e-Government) initiatives. The Internet has provided opportunities for citizens and businesses alike to engage in various public services online. Such engagements have often been carried out either through direct engagement with central government (Janowski, 2015; Weerakkody et al., 2016), local intermediaries (Weerakkody et al., 2013) or by utilising existing online resources at local government authorities (LGAs ${ }^{1}$ ) level (Omar et al., 2017; Karkin, and Janssen, 2014). This has contributed towards

\footnotetext{
${ }^{1}$ Local Government Authority in the UK is equivalent to County or Municipality in the US
} 
modernising and realising citizen-centred services through cohesive policies and programmes that join-up service delivery across local government (Omar et al., 2017; Weerakkody and Dhillon, 2008; Ferlie 2007).

Although today many countries have successfully implemented e-Government (throughout this article we refer to e-Government as the usage of information and communication technology in governmental services), in most cases the focus has been to provide existing services in their current state without significant improvements or efficiency gains (Weerakkody and Dhillon 2008). Consequently, many of these governments are now embarking on the transformation of their internal inter departmental and external inter organisational business activities and supporting enterprise systems (ES) (Sivarajah et al., 2015; Janssen, 2011) that make up their service chains. In the UK, the government has pursued a far-reaching and ambitious programme of innovation and radical change in the public sector aimed transforming services. These changes are branded under the umbrella of e-Government and the incentives for implementing these changes have been motivated by the desire to improve efficiency, reduce costs and wastage for government and introduce citizens' centric public services at a local level that are transparent and accessible. Yet, very few LGAs in the UK are realising these objectives (Weerakkody and Dhillon 2008). While many studies have been conducted to understand the reasons for such a lack of success, these studies have often resulted in identifying archetypical organisational or technology issues which have thus failed to address the fundamental reasons for the lack of effectiveness in the e-Government service chain.

Unlike the private sector where research has focused on supply chains to understand the flow of goods, services and related information (Peng et.al., 2016; Lee et. al., 2014; DeGroote and Marx, 2013). Few studies have set out to examine the fundamental activities and how 
information is exchanged between activities in e-Government from a service chain perspective and its impact on the society (De Camargo Fiorini and Jabbour, 2017). The service chain principles have been proven to offer the best sequential overview of an organisation's business activities and the value margin they create (Heintzman and Brian, 2005). Although the implementation of e-Government has incurred huge costs to governments, we have identified only a few studies in the literature (e.g. Beynon-Davies and Martin 2004, Holden and Fletcher 2005, McAdam et al. 2011) that have examined eGovernment from a service chain perspective. Rather, most existing studies have attempted to analyse the challenges and complexities of e-Government either from an organisational (i.e. management, process, political, financial) or technology (legacy systems, interoperability, integration) perspectives. While these studies help understand how e-Government should be implemented and the challenges and complexities that are faced particularly by LGAs when implementing e-Government, they often fail to delineate how the various challenges relate to and impact the primary and support activities that all LGAs need to perform to offer the various implemented e-government services. In an LGA context, primary activities are those that incur cost to local government and contribute directly to the delivery of a service and secondary activities are those that incur costs but only indirectly contribute to a service by supporting the primary activities (see Porter and Millar 1985).

Given the aforementioned context, this research aims to explore the complexities and challenges involved in implementing and delivering a key local e-Government services in the UK from a service chain perspective to: a) better understand how primary and support activities contribute to the delivery of a particular e-service, and b) what impact do internal and external stakeholders have on the activities that influence the efficient (i.e. well organised) and effective (i.e. value added and useful) delivery of integrated e-services. In 
doing so, we aim to contribute towards the understanding of how to better structure information and workflows between internal activities and stakeholders such as employees and managers and improve collaboration between external activities and stakeholders such as private and nongovernmental organisations and governmental agencies.

\section{Case Analysis}

This case study explores the challenges that LGAs may face when moving from providing basic e-Government services to more comprehensive and 'joined-up' services. This case studies explores the impact of these issues in real life: the execution of a key public service in LGA and how the service chain facilitates the efficient and effective delivery of this service through the various activities performed and information exchanged between the stakeholders involved in the process is examined.

The case study conducted in LGA-X explores how local government perform the service of removing an abandoned motor vehicle (AMV) when citizens report such cases. The aim was to examine the sequence of events and activities from a service chain dimension and to identify the type of value that is created to local government (the service provider) and citizen (the service user) as a result of delivering this service.

This study uses a qualitative research approach utilising semi-structured interviews, observations and document reviews in a case study setting. Qualitative research offers insights into questions that address the way people think about a certain subject and why they think in that way (Ruyter and Scholl 1998). Research methods as those mentioned above provide in-depth insight, flexibility and the results obtained are rich with ideas (Creswell 2003). Case studies could lead to a multidimensional perspective (Whitman and Woszczynski 2004), generate alternative explanations based on the different participants' views, therefore allowing to determine contradictions and misunderstandings (Flick 2006). Case studies are 
also appropriate where the purpose is to study current events, and where it is not necessary to control behavioural events or variables (Yin 2003).

Due to the lack of understanding and the complexity involved in the area, a semi-structured interview approach was used in the research (Yin 2003). Open-ended semi-structured interviews were conducted with five key figures (e-Government project manager, customer relationship manager, senior vehicle inspector, IT systems analyst, customer service administrator) involved in the e-Government implementation programme in a large local authority based in West London UK (hereafter referred to as LGA-X). Emails and telephone conversations were exchanged with senior management, which led to the identification of relevant people to interview. The interviews were then conducted by researchers visiting the LGA premises over a three-month period.

Before the interviews, participants were emailed with key themes that would be covered during the interviews so that they could familiarise themselves with the research (Smith 2004) and were given a consent form to read. The interviews lasted approximately one and a half hours, and were undertaken in a meeting room of the LGA building. This allowed the researchers and respondents to build the necessary rapport and privacy for the required questions. To facilitate the analysis the interviews were audio recorded with the participants consent. To ensure the validity and accuracy of the results transcripts of the interviews were sent back to the respondents and followed up with brief telephone and email exchanges. After the interviews, the researchers were shown around the respective departments where the eGovernment service under study was performed and could observe the activities and data flows being executed.

Thematic analysis was used with the information encoded during the process being used identify themes (Boyatzis 1998). Data was triangulated by comparing and contrasting the 
interview findings with observations and document reviews to validate and verify the findings of the primary data with secondary information (Saunders et al. 2002).

Based upon the information gathered from interviewing the service area participants from the AMD, the data flow diagram in Figure 1 illustrates the overall procedures of the entire service of reporting and removing an abandoned vehicle.

When a citizen reports an abandoned motor vehicle he/she informs the local authority. The enquiry is sent to the central customer relationship management (CRM) system at the customer contact centre. The enquiry is automatically logged onto the system and a customer service administrator (CSA) is alerted about the enquiry via email. Thereafter, the CSA determines whether the information provided by the citizen is accurate by checking the system to see if the vehicle has been reported before. If the vehicle is taxed the process ends. If the vehicle is untaxed the enquiry is processed and flagged on the CRM system. The information is sent to the abandoned vehicle section that prints out details of the enquiry and gives it to an inspector. The inspector must visit the location, assess the vehicle condition and document the assessment. If the vehicle is taxed and does not look abandoned the local authority cannot remove the vehicle and the process ends. However, if the vehicle is determined abandoned the inspector affix a message onto the vehicle stating that the local authority is aware of the vehicle. If the vehicle still remains after two days, the inspector affixes another notice stating that the vehicle will be removed in 24 hours. 


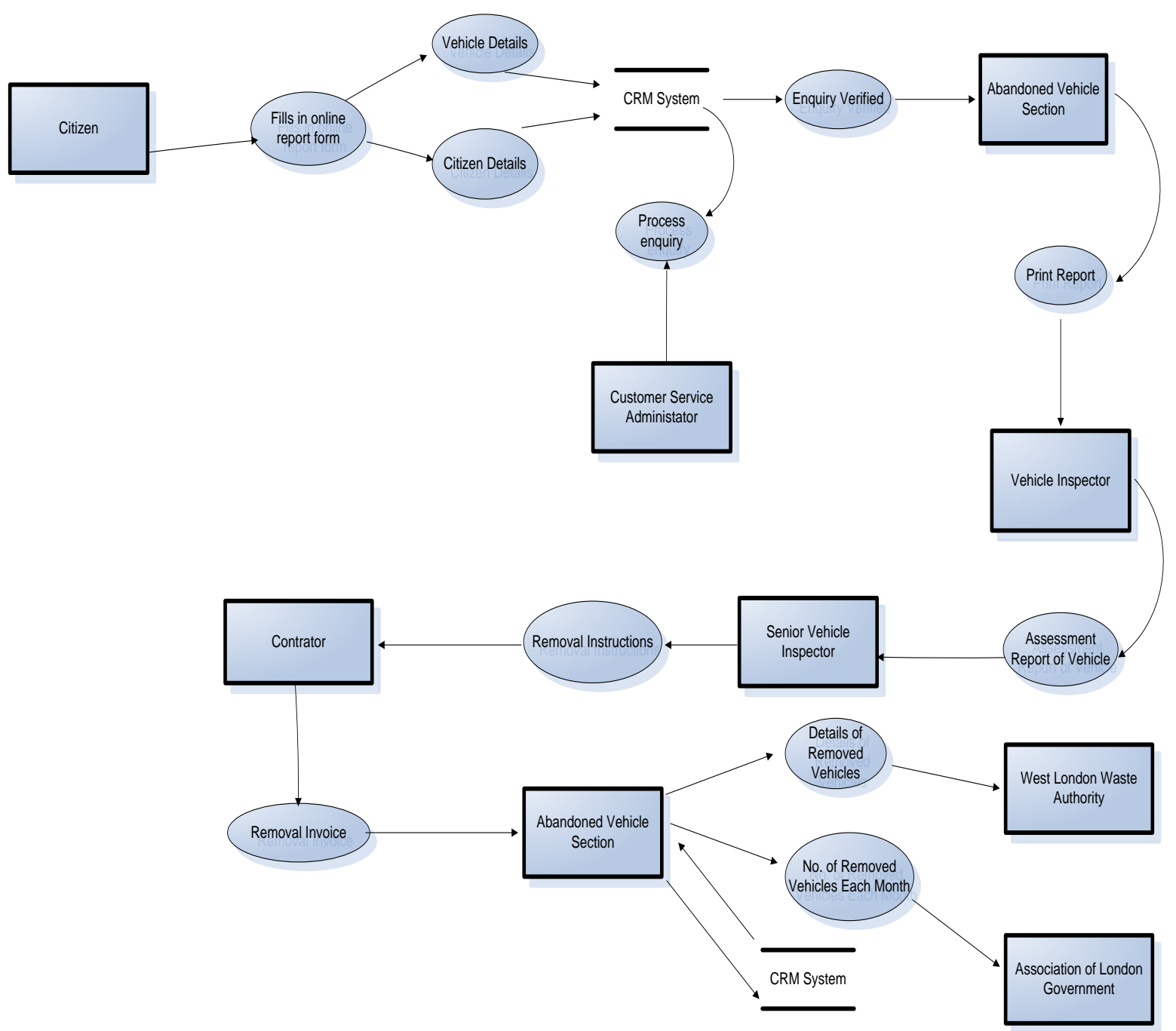

Figure 1: Data Flow Diagram for Abandonment of Vehicles

Once the assessment report has been completed it is given to the senior vehicle inspector, who has the final decision. If the senior inspector decides to remove the vehicle then a legal document to remove the vehicle is sent through to an external contractor. The contractor is responsible for the actual removal and disposal of the vehicle. The removal instructions are physically delivered to the contractor. Once the vehicle has been removed all the details are logged onto the CRM system and any statistical information is distributed to the West London Waste Authority and the Association of London Government. 
This scenario contradicts LGA-X's vision for delivering 'joined-up' e-government services. The sequence of activities also highlights inefficiencies in information exchange and process management in the AMV service chain. The key problems are delays caused when retrieving and exchanging information between different internal departments as well as external entities. This is further intensified by delays that occur when physically delivering or handing over documentation from one employee (vehicle inspector) to another (senior inspector) or when information and documents are passed to the external contractors. The business activities and supporting ES that make up the AMV service were operating in isolation from each other resulting in several communication problems. Furthermore, it was pointed out by the CRM manager that prioritising the various citizens' complaints and reports of environmental issues (which is the category of service that the AMV example falls into) was a big challenge. One reason, as suggested by the CRM manager “....is the lack of IT support to report and prioritise the environmental issues and feed them to the environmental officers, in this case the vehicle inspectors, in real time." Although citizens used an online form for reporting for a large part of the process, the LGA used manual communication methods and information exchange in the back office to execute the service.

Overall, the level of integration and information exchange between activities and stakeholders (service chain partners) was poor thus resulting in delays, inefficiencies and lack of transparency in the service. Therefore, transforming the AMV service requires a radical reengineering of the service chain to better synchronise the primary and secondary activities and to harmonise the supporting ES to facilitate better information exchange between internal departments and external stakeholders [government agencies (Department of Vehicles and Licensing Agency: DVLA and Police in this instance), employees (vehicle inspectors, administrators and CSA in this instance), and business partners (contractors and 
environmental services in this instance)]. This mirrors the need for cross agency process reengineering and integration (as suggested by Champy (2002)).

In Figure 2, the AMV scenario is mapped onto the service chain model. This shows how the various information flows take place between internal activities (primary and secondary) in the service chain and between internal and external stakeholders. The value created in the service chain for both the local authority and citizens by delivering the AMV service as a local e-government service can be delineated as follows:

- Cost of delivering the AMV service to the tax payer (as opposed to the pre eGovernment era),

- Citizens satisfaction with the AMV service,

- Quality of the AMV service (i.e. level of professionalism with which the service is delivered),

- Efficiency of the service,

- Transparency of the service,

- Level of adoption of the AMV service,

- Level of stakeholder (service chain partner) collaboration and participation in the delivery of the AMV service (compared to pre e-Government),

- The degree of trust created between the citizens using the AMV service and local government,

- Accessibility and usability of the service. 


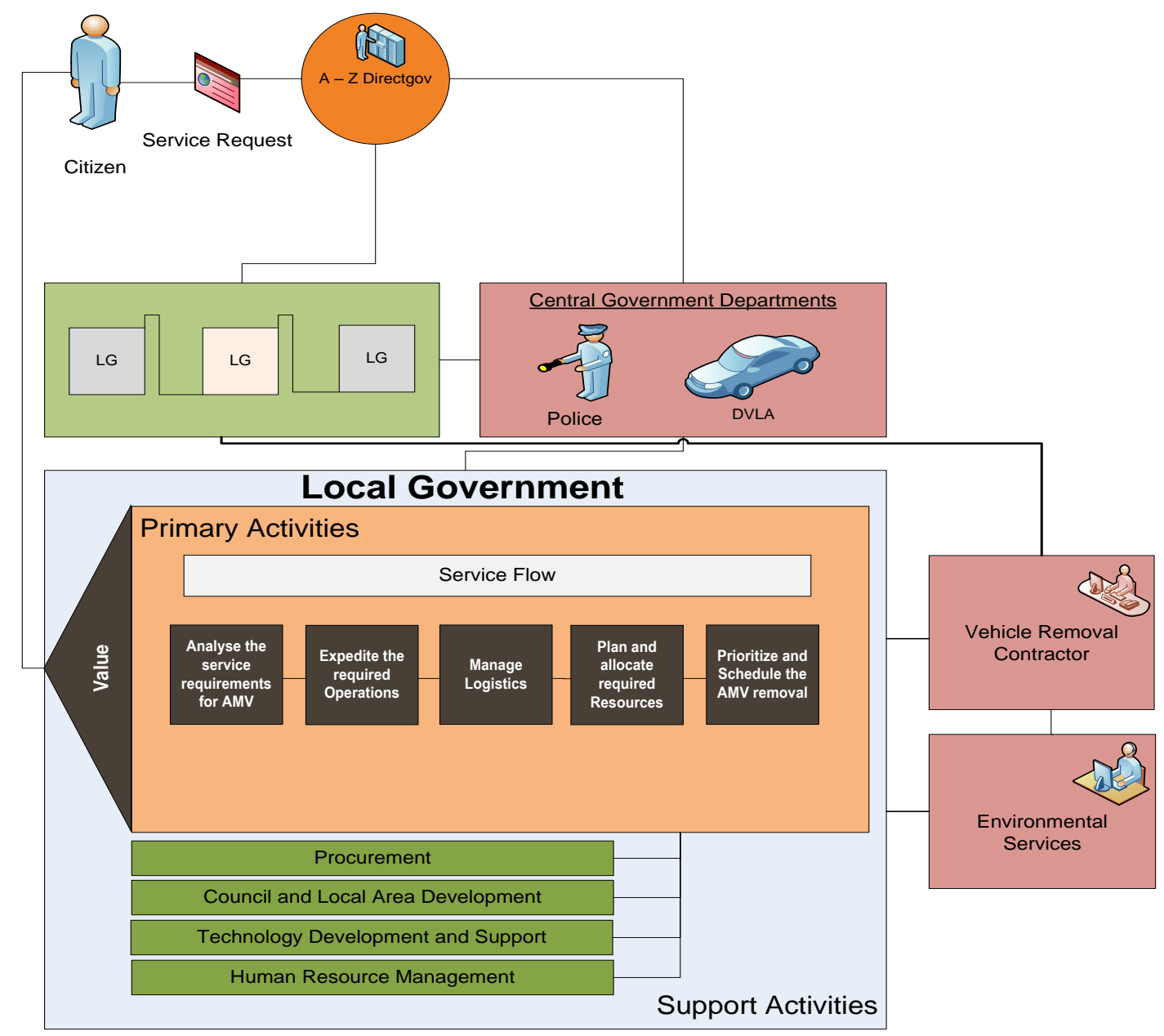

Figure 2: Value Chain for the Reporting and Abandonment of Motor Vehicles

\section{Lessons Learned}

As seen in the case study, e-Government service chains are challenged with integration and synchronisation problems resulting in poor information exchange and collaboration between various stakeholders involved in service delivery. The integration and information exchange between customer facing primary activities and back office support activities and those of the various stakeholders is complicated because different departments and organisations use different resources and ES and have varying competencies and authority (Bekkers 2007, Kamal et al. 2009). These variations are clear in the context of the AMV where external stakeholders such as the DVLA and local contractors that remove the vehicle obviously use 
different ES and have different priorities for their own primary and support activities. This context offers clarity for the second research question illustrating that external stakeholders have a major impact on the e-Government service chain and the delivery of integrated services; the AMV example failed to demonstrate integrated e-Government service delivery due mainly to cross agency collaboration and information exchange problems. Lack of synergy between local government, central government and other public sector and private agencies' activities and ES prove that more needs to be done in terms of transforming the local government service chain if 'joint up' services are to be delivered.

As service chain activities have been relatively little researched in a public-sector environment, there is scope for local government authorities implementing e-Government to learn from the lessons of organisational change in the private sector. Certainly, before embarking on transforming their service chains, they can identify factors that may challenge such change in the public sector (Cassell 2008, Irani et al. 2007). Some of the key high level challenges that organisations faced during the business process reengineering movement when radically changing their processes and ES included: resistance from employees, legacy systems constraints, cultural and political constraints, lack of senior management commitment, negative employee attitude and resistance to change (Mumford 1994, Weerakkody and Currie 2003, Weerakkody and Hinton 1999, Willcocks 1995). For the public sector which is described as bureaucratic, functionally oriented, and legacy driven (Weerakkody et al. 2007) these challenges may be even more severe. Hence, better understanding of the key service delivery challenges will help facilitate the transformation of e-Government service chains in local government (Larsen and Klischewski 2004).

While this case study has identified a key example of service chain inefficiencies at a local government level, it can be argued that there will be other local authorities that repeat the same inefficient processes. Therefore, to realise more customer-focused and 'joined up' 
service delivery in the UK (vis-à-vis well synchronised service chains), public sector agencies will require a substantial level of integration of back-end ES (Beynon-Davies and Martin 2004, Weerakkody and Dhillon 2008). In this context, the implementation of fully integrated enterprise resource planning (ERP) systems can prove to be helpful in streamlining business processes and seamless information flows (Howcroft et al. 2004, Wagner and Newell 2004). Already a number of LGAs (e.g. Leeds City Council, Birmingham City Council) have successfully adopted such systems to integrate their activities and stakeholders in the service chain (Davies 2008). While these efforts are encouraging, more research is needed to understand how broader organisational forces such as established social and cultural norms, workflows and legacy systems will be affected by the implementation of large ES in local government.

Drawing from the above examples more local authorities will need to further explore technologies such as service oriented architecture (SOA) and web services that can offer fast and cost-effective solution to LGAs by helping to retain many existing (functional) legacy applications in the LGA, but instead of staying in relative isolation from each other, they can be integrated to create new services that are more attuned to the needs of the citizens (Weerakkody et al. 2007). Yet, from an organisational perspective, the paradigm shift and change of culture that needs to be realised to change these processes would mean that LGAs will need to breakdown their departmental or silo culture and overcome resistance to change as seen in other forms of organisational change such as business process reengineering (Sahay and Walsham 1997, Weerakkody and Hinton 1999). Nonetheless improving key services such as AMV and consequently succeeding at a local level is imperative as successful local best practices can be mirrored at national level (Hackney and Jones 2002). Realising this vision will need to overcome the various challenges faced by LGAs as seen in the AMV example. In Table 1, the key challenges impacting local e-government service 
delivery as extrapolated from the LGA-X example are outlined comparing their implications

to both local government and citizens from a 'service chain' dimension.

Table 1: The Key Service Chain Challenges that Impede Integrated Local E-Government Service Delivery

\begin{tabular}{|c|c|c|c|}
\hline \multirow{2}{*}{ Challenge } & \multirow{2}{*}{ Description } & \multicolumn{2}{|c|}{ Implications } \\
\hline & & Organisational & Citizens \\
\hline Communication & $\begin{array}{l}\text { Lack of communication amongst internal } \\
\text { stakeholders and between internal and external } \\
\text { stakeholders in the service chain }\end{array}$ & $\begin{array}{l}\text { Different departments } \\
\text { unable to execute their } \\
\text { duties efficiently }\end{array}$ & $\begin{array}{l}\text { Service errors } \\
\text { and delays }\end{array}$ \\
\hline $\begin{array}{l}\text { Information } \\
\text { Exchange }\end{array}$ & $\begin{array}{l}\text { Lack appropriate mechanisms for information } \\
\text { exchange between primary and secondary } \\
\text { activities in the service chain and between } \\
\text { internal and external stakeholders }\end{array}$ & $\begin{array}{l}\text { Different departments } \\
\text { unable to execute their } \\
\text { duties efficiently }\end{array}$ & $\begin{array}{l}\text { Service errors } \\
\text { and delays }\end{array}$ \\
\hline Integration & $\begin{array}{l}\text { Lack of integration between primary and } \\
\text { secondary activities in the service chain due to } \\
\text { departmental boundaries }\end{array}$ & $\begin{array}{l}\text { Avoidable costs being } \\
\text { incurred }\end{array}$ & $\begin{array}{l}\text { Service errors } \\
\text { and delays }\end{array}$ \\
\hline $\begin{array}{l}\text { Information } \\
\text { Systems }\end{array}$ & $\begin{array}{l}\text { Lack of interoperability between IS/IT systems } \\
\text { that support the internal activities and between } \\
\text { those of the external service chain partners or } \\
\text { stakeholders }\end{array}$ & $\begin{array}{l}\text { Management information } \\
\text { being delayed or } \\
\text { unavailable }\end{array}$ & $\begin{array}{l}\text { Service errors } \\
\text { and delays }\end{array}$ \\
\hline Bureaucracy & $\begin{array}{l}\text { Many official procedures and guidelines } \\
\text { promoting a mentality for the 'need for } \\
\text { authorisation'-impeding efficiency and } \\
\text { effectiveness in local government }\end{array}$ & $\begin{array}{l}\text { Avoidable costs being } \\
\text { incurred }\end{array}$ & Service delays \\
\hline Transparency & $\begin{array}{l}\text { Lack of transparency in local government } \\
\text { activities means citizens cannot track their } \\
\text { service request and the government loses the } \\
\text { sense of accountability of the services }\end{array}$ & $\begin{array}{l}\text { Employees losing sense } \\
\text { of responsibility and } \\
\text { accountability }\end{array}$ & $\begin{array}{l}\text { Citizens losing } \\
\text { trust in } \\
\text { government }\end{array}$ \\
\hline Cost of Service & $\begin{array}{l}\text { The economic justification and/or return on } \\
\text { investment for e-Government service } \\
\text { provisioning becomes hard to justify due to } \\
\text { inherent service chain deficiencies }\end{array}$ & $\begin{array}{l}\text { Avoidable costs being } \\
\text { incurred }\end{array}$ & $\begin{array}{l}\text { Poor value for } \\
\text { tax payers } \\
\text { money }\end{array}$ \\
\hline $\begin{array}{c}\text { Citizen } \\
\text { Satisfaction }\end{array}$ & $\begin{array}{l}\text { Citizen satisfaction of e-Government services } \\
\text { becomes hard to manage due to lack of } \\
\text { efficiency in the service chain; this often results } \\
\text { in poor adoption of e-Government services } \\
\text { offered by LGA }\end{array}$ & $\begin{array}{l}\text { Widening the } \\
\text { relationship gap between } \\
\text { local government and } \\
\text { citizens }\end{array}$ & $\begin{array}{l}\text { Citizens losing } \\
\text { interest in e- } \\
\text { Government } \\
\text { services }\end{array}$ \\
\hline
\end{tabular}

As discussed earlier, the various challenges outlined in table 1 were impacting both the local council and citizens and therefore failing to deliver improved outcomes in service delivery through e-government. While in this particular case the impacts to the local council were both financial and operational, for citizens it was a case of losing interest and trust in egovernment services. Thus, a key lesson that is learnt from this case study is the effect that siloed organisation structure and lack of processes and systems integration between 
stakeholders in the service chain can have on realising improved service outcomes in an egovernment context.

The findings in the study offer a number of lessons to LGA's, e-Government practitioners and policy makers. These can be themed into the following three areas:

Information Exchange and Stakeholder Collaboration: Local e-Government services are often fraught with many challenges and among these information exchange and collaboration between service chain partners (stakeholders) were found to be the most significant barrier to efficient service delivery in the example studied. This challenge is linked to: a) the lack of interoperability of the ES that support the internal activities in the service chain as well as between the various stakeholders' systems, and b) lack of communication and physical delays in passing information between various stakeholders in the service chain. To address the ES integration issues, Web Services/SOA may prove to be a cost effective EAI concept for eGovernment both in the long and short term. In fact, recent estimates indicate that LGAs are already adopting Web Services based solutions (Computer Weekly, 2010). Therefore, the technical issues are being addressed and more effort is needed to streamline the physical aspects of communication and information exchange as well as removing some of the bottlenecks and red tape in LGA service chains.

Using a Service Chain dimension to analyse e-Government: Local e-Government services are often implemented and delivered without much focus on how the service chain activities and stakeholders will be synchronised. The focus is usually on the technology and the front end (or customer service) aspects of service delivery. Therefore, re-examination and reengineering of LGA e-Government services with a services chain dimension or focus will offer greater opportunity to streamline activities and justify any financial resources that are spent doing this as the value created from services will be more visible. 
Identifying the value created in e-Government services: The value created from typical local e-Government services such as the AMV can be summarised as: the cost savings achieved from delivering a service; higher levels of citizens satisfaction with the service; improved quality and level of professionalism associated with the service; improved service efficiency; improved service transparency; higher levels of user service adoption; increased stakeholder collaboration and participation in the delivery of the service; higher degree of trust between the citizens using the service and local government; and improved service accessibility and usability for the citizen. These offer the rationale and justification for delivering local government services using the e-Government channel. Furthermore, using the service chain dimension to analyse the services provided by LGAs will help make these benefits more visible.

Based on the evidence from this case, this article recommends that local government authorities should first review and comprehend the challenges they are likely to face when attempting to change established process through e-government. They should consult the key stakeholders in the service value chain and understand the process that needs to be changed from end-to-end and be willing to work together with the stakeholders. If this is achieved, the various challenges identified in this study (table 1) are likely to be overcome to create a seamless process through e-government.

\section{Conclusions}

The UK public sector has for many years advocated that ICT has the potential to deliver its services more quickly and at a lower cost (Jas and Skelcher 2014, Irani et al. 2007). However, despite several LGAs meeting their objectives, prior research in the context exhibits several difficulties impeding the ICT-enabled transformation of service chains, including the non- 
integrated nature of their IT infrastructure not allowing LGAs to deliver end-to-end integrated services (McIvor et al. 2002, Weerakkody et al. 2007). This has resulted in a wide range of technologies and disparate ES being implemented that are incapable of interoperating with each other and eventually leading to islands of information (Janssen and Cresswell 2005). In the last few years these challenges have been overcome in some LGAs by transforming their customer facing processes and improving back office ES integration through SOA driven enterprise application integration (EAI) and the implementation of integrated ERP systems (Davies 2008, Weerakkody et al. 2007). Furthermore, further research is needed to better understand their benefits and value added to citizens.

This case study has shown that AMV is faced with several challenges and complexities that are centred on information exchange and collaboration between stakeholders in the service chain. Inefficiencies seen in the AMV case were largely due to delays in information sharing and lack of interoperability between the different ES supporting the primary and support activities and between different external stakeholders that contributed to the service chain. By exploring these issues, this case study has attempted to highlight the importance of studying e-Government service delivery from a 'service chain' dimension. Furthermore, by mapping a key service such as the AMV onto the service chain model, it is clear that the value created from the service can be better highlighted showing the benefits of the service to both the government and citizens. This is particularly important in the current climate of economic downturn and public-sector spending restrictions.

\section{References}

Bekkers, A., 2007. "The Governance of Back-Office Ontegration.” Public Management Review, 9(3):377-400. 
Beynon-Davies, P. and Martin, S., 2004. "Electronic Local Government and the Modernisation Agenda: Progress and Prospects for Public Service Improvement.” Local Government Studies, 30(2): 214-229.

Boyatzis, R., 1998. Transforming Qualitative Information. Sage Publications, USA.

Cassell, M. 2008. "Why Governments Innovate: Adoption and Implementation of Open Source Software by four European Cities." International Public Management Journal, 11(2):193-213.

Champy, J. 2002. X-Engineering the Corporation: Reinventing Your Business in The Digital Age, Warner Books.

Computer Weekly, 2010. Council spend on web services tops £19m, Available at: http://www.computerweekly.com/Articles/2010/04/26/241035/Council-spend-onweb-services-tops-16319m.htm, last accessed on 01/06/10

Creswell, J., 2003. Research design, qualitative, quantitative, and mixed methods approaches. Second Edition, Sage Publications, Thousand Oaks, London.

Davies, J., 2008. Councils Prepare to Adopt SOA, available at: http://www.computing.co.uk/computing/analysis/2222939/councils-prepare-adoptsoa, Accessed: 13/11/2014.

De Camargo Fiorini, P.; Jabbour, C.J.C. (2017) Information systems and sustainable supply chain management towards a more sustainable society: Where we are and where we are going. International Journal of Information Management, 37(4): 241-249.

DeGroote, S.E., Marx, T.G., 2013. The impact of IT on supply chain agility and firm performance: an empirical investigation. International Journal of Information Management, 33 (6): 909-916.

Ferlie, E. 2007. "Complex Organisations and Contemporary Public Sector Organisations." International Public Management Journal, 10(2):153-165. 
Flick, U., 2006. An introduction to qualitative research. Third Edition, Sage Publications, Thousand Oaks, London.

Hackney, R., and Jones, S., 2002. Towards E-government in the Welsh (UK) Assembly: an Information Systems Evaluation, ISOneWorld Conference and Convention, 2002, Las Vegas, USA.

Heintzman, R. and Marson, M. 2005. "People, Service and Trust: Is there a Public Sector Service Value Chain?” International Review of Administrative Sciences, 71(4):549575.

Holden, S.H. and Fletcher, P.D. 2005. "The Virtual Value Chain and E-Government Partnership: Non-Monetary Agreements in the IRS E-File Program.” International Journal of Public Administration, 28:643-664.

Howcroft, D., Newell, S. and Wagner, E., 2004. "Editorial: Understanding the Contextual Influences on Enterprise System Design, Implementation, Use and Evaluation.” Journal of Strategic Information Systems, 13(4):271-277

Irani, Z., Elliman, T. and Jackson, P. 2007. "Electronic Transformation of Government in the UK: A Research Agenda.” European Journal of Information Systems, 16(4):327-335. Janssen, M. and Cresswell, A., 2005. “An Enterprise Application Integration Methodology for E-Government.” Journal of Enterprise Information Management, 18(5):531-547.

Janssen, M. 2011. "Sociopolitical Aspects of Interoperability and Enterprise Architecture in e-Government." Social Science Computer Review, 1-13.

Janowski, T. (2015). Digital government evolution: From transformation to contextualization. Government Information Quarterly, 32(3), 221-236.

Jas, P., and Skelcher, C. 2014. "Different Regulatory Regimes in Different Parts of the UK? A Comparison of Narrative and Practice in Relation to Poor Performance in Local Government." Local Government Studies, 40(1):121-140. 
Kamal, M.M., Weerakkody, V. and Jones, S., 2009. "The Case of Enterprise Application Integration in Facilitating E-Government Services in a Welsh Authority." International Journal of Information Management, 29(2):161-165.

Karkin, N., \& Janssen, M. (2014). Evaluating websites from a public value perspective: A review of Turkish local government websites. International Journal of Information Management, 34, 351-363.

Larsen, M., Klischewski, R., 2004. "Process Ownership Challenges in IT-Enabled Transformation of Interorganizational Business Processes.” Hawaii International Conference on System Sciences, 1-11

Lee, H., Kim, M. S., \& Kim, K. K. (2014). Interorganizational information systems visibility and supply chain performance. International Journal of Information Management, 34(2), 285-295

Lee, H., Sivarajah, U., Molnar, A., Weerakkody, V. and Irani, Z. 2015. “A User Satisfaction Study of London's Congestion Charge e-Service: A Citizen Perspective.” International Journal of Electronic Government Research (IJEGR), 11(2):35-50.

McAdam, R., Hazlett, S. A., and Johnston, S. (2011). "Establishing ex ante Public Construction Supply Chain Guidelines in the Public Procurement of Schools' Estate.” International Journal of Public Sector Management, 24(3):250-273.

McIvor, R., McHugh, M., Cadden, C., 2002. "Internet Technologies: Supporting Transparency in the Public Sector." The International Journal of Public Sector Management, 15(3):170-187.

Mumford, E., 1994. "New Treatments or Old Remedies: Is Business Process Reengineering really Socio-technical design?” Journal of Strategic Information Systems, 3(4):313326. 
Omar, A., Weerakkody, V., \& Sivarajah, U. (2017). Digitally enabled service transformation in UK public sector: A case analysis of universal credit. International Journal of Information Management, 37(4), 350-356.

Peng, J., Quan, J., Zhang, G., \& Dubinsky, A. J. (2016). Mediation effect of business process and supply chain management capabilities on the impact of IT on firm performance: Evidence from Chinese firms. International Journal of Information Management, 36(1), 89-96

Porter, M.E. and Millar, V.E., 1985. "How Information gives you Competitive Advantage." Harvard Business Review, 63(4):149-160.

Ruyter, K.D. and Scholl, N., 1998. "Positioning Qualitative Market Research: Reflections from Theory and Practice." Qualitative Market Research: An International Journal, $1(1): 7-14$.

Sahay, S. and Walsham, G., 1997. "Social Structures \& Management Agency in India." Organisation Studies, 18:415-444.

Saunders, M., Lewis, P., Thornhill, A., 2002. Research Methods for Business Students. $3^{\text {rd }}$ Edition, Prentice Hall, London

Sivarajah, U., Irani, Z., \& Weerakkody, V. (2015). Evaluating the use and impact of Web 2.0 technologies in local government. Government Information Quarterly, 32(4), 473487.

Wagner, E. and Newell, S., 2004. "Best for whom?: The Tension between 'best practice' ERP Packages and Diverse Epistemic Cultures in a University Context.” Journal of Strategic Information Systems, 13(4):305-328.

Weerakkody, V. and Dhillon, G., 2008. "Moving from E-Government to T-Government: A Study of Process Re-engineering Challenges in a UK Local Authority Perspective." International Journal of Electronic Government Research, 4(4):1-16.Weerakkody, V., 
El-Haddadeh, R., Al-Sobhi, F., Shareef, M. A., \& Dwivedi, Y. K. (2013). Examining the influence of intermediaries in facilitating e-government adoption: An empirical investigation. International Journal of Information Management, 33(5), 716-725

Weerakkody, V., Omar, A., El-Haddadeh, R., \& Al-Busaidy, M. (2016). Digitally-enabled service transformation in the public sector: The lure of institutional pressure and strategic response towards change. Government Information Quarterly, 33(4), 658668

Weerakkody, V., Janssen, M. and Hjort-Madsen, K., 2007. "Realising Integrated EGovernment Services: A European Perspective." Journal of Cases in Electronic Commerce, 3(2):14-38.

Whitman, M. and Woszczynski, A., 2004. The handbook of information systems research, Idea group publishing, Hershey, USA.

Willcocks, L., 1995. False Promise or Delivering the Goods? Recent Findings On The Economics And Impact Of Business Process Reengineering, European Conference On IT Investment Evaluation.

Yin, R.K., 2003. Case Study Research: Design and Methods. $3^{\text {rd }}$ Edition, Sage Publications, London. 